\title{
Intrapartum transfers from the Birth Centre to the Obstetric Unit in 2017 - analysis of
} reasons

\section{Analiza przyczyn transferów śródporodowych z Domu Narodzin do Oddziału Porodowego w roku 2017}

\author{
Aleksandra Łukasiewicz', Barbara Baranowska² , Edyta Dzierżak-Postek³, \\ Piotr Węgrzyn ${ }^{4}$
}

'Studentka kierunku Położnictwo, Wydział Nauk o Zdrowiu, Warszawski Uniwersytet Medyczny/ Student of midwifery, Faculty of Health Sciences, Medical University of Warsaw 2Zakład Położnictwa, Centrum Medyczne Kształcenia Podyplomowego/Centre of Postgraduate Medical Education 3Centrum Medyczne „Żlazna" /"Żelazna”" Medical Center ${ }^{4}$ Klinika Położnictwa i Perinatologii, Warszawski Uniwersytet Medyczny/ Department of Obstetrics and Perinatology, Medical University of Warsaw

Barbara Baranowska: 0000-0003-2723-9604

CORRESPONDING AUTHOR/AUTOR DO KORESPONDENCJ:

Barbara Baranowska

Zakład Położnictwa, Centrum Medyczne Kształcenia Podyplomowego

ul. Żelazna 90, 01-004 Warszawa

e-mail: bbaranowska@gmail.com

STRESZCZENIE

Słowa kluczowe:

ABSTRACT

Key words:

\section{ANALIZA PRZYCZYN TRANSFERÓW SRÓD PORODOWNCH Z DOMU NARODZIN DO OD DZIARU PORODOWEGO}

\section{W ROKU 2017}

Wprowadzenie. Standard opieki okołoporodowej daje kobiecie prawo do świadomego wyboru miejsca porodu. Domy Narodzin prowadzone przez położne realizują wizję niezmedykalizowanego porodu w warunkach intymnych, zbliżonych do domowych.

Cel pracy. Celem pracy jest określenie przyczyn transferów z Domu Narodzin do Oddziału Porodowego oraz wskazanie cech społecznodemograficznych rodzących, które mogą predysponować do transferu.

Materiał i metodyka. Badanie przeprowadzono w oparciu o analizę dokumentacji medycznej rodzących transferowanych z Domu Narodzin do Oddziału Porodowego Szpitala św. Zofii w Warszawie. Grupę badaną stanowiło 88 kobiet, które poddane były transferowi. Wyniki. Najliczniejszą grupę stanowiły rodzące w wieku 30-34 lata. Większość była pierworódkami oraz posiadała wykształcenie wyższe. Transfery śródporodowe związane były ze stanem położniczym matki, stanem płodu lub zaburzeniem przebiegu porodu. Wnioski. Zahamowanie postępu porodu jest główną przyczyną transferów. Najczęściej transferowaną grupą kobiet są pierworódki po 30 roku życia, z wykształceniem wyższym, przyjęte do porodu po 40 tygodniu ciąży z rozwarciem poniżej $4 \mathrm{~cm}$.

Domy Narodzin, transfer śródporodowy, miejsce porodu

INTRAPARTUM TRANSFERS FROM THE BIRTH CENTRE TO THE OBSIETRIC UNIT IN 2017 - ANALYSIS OF REASONS Introduction. The standard of perinatal care gives the woman the right to consciously choose the place of birth. Birth Centres (BC) run by midwives implement a vision of a non-medicalized birth in intimate homelike conditions.

Aim. The aim of the study is to determine the causes of transfers from the Birth Centre to the Obstetric Unit and to indicate the social and demographic characteristics of the women giving birth that may predispose to transfer.

Material and methods. The study was based on the analysis of the medical records of women who were transferred from the BC to the St. Sophia Obstetric Unit in Warsaw. 88 women who were transferred constituted the study group.

Results. The most numerous group were women giving birth aged 30-34. The majority were giving birth for the first time and had higher education. Intrapartum transfers were related to the mother's obstetric condition, fetal condition or disruption of the childbirth. Conclusions. Failure to progress of labour is the main cause of transfers. The women giving birth for the first time aged 30 and over, admitted for to the BC after 40 weeks of pregnancy and dilation below $4 \mathrm{~cm}$ were the most often transferred group of women. Birth Centre, intrapartum transfers, place of birth 


\section{INTRODUCTION}

Until the end of the 19th century, births used to take place mainly at home [1]. The situation began to change from the second half of the 20th century. Childbirth has become a medical event subject to hospital procedures and controls [2]. This led to a significant reduction in the mortality and morbidity of women and newborns, but also contributed to the so-called "medicalization" of obstetrics. Childbirth was even compared to surgical procedures [3]. In the seventies, the liquidation of delivery room run by midwives began. This was connected with the mass formation of obstetrics and gynaecological centres in the cities. It became standard to give birth in hospitals, and the midwife's competence was gradually reduced [1].

In recent years, the idea of a natural birth has begun to revive. This is associated with fundamental changes in perinatal care. The Regulation of the Minister of Health on the organizational standards of perinatal care gives the woman the right to choose the place of birth consciously [4]. According to the data of the World Health Organization, natural childbirth concerns $70-80 \%$ women and it does not have to take place in a hospital [5]. In Poland, the share of alternative care against the hospital is small, however, pregnant women more often decide to give birth with the help of a midwife, but in non-hospital settings.

The act of July 5, 1996 on nurse and midwife professions stresses that a midwife is a competent person to take care of a woman in a physiological pregnancy, helping her give natural birth and taking care of a newborn baby and mother in the postpartum period [6]. Birth Centres run by midwives implement a vision of delivery in intimate conditions, close to home, but providing hospital facilities in close proximity. The philosophy of the Birth Centre is the recognition of pregnancy and birth as a natural process in the life of a woman [7]. Midwives focus on holistic care for the mother and her family, combining in the physical, mental and spiritual realms. Medical activities should be limited as much as possible, however, it cannot be done at the expense of the safety of the woman and her child [8].

\section{MATERIALS AND METHODS}

The study was based on a retrospective analysis of the medical records of women who were transferred from the Birth Centre to the Obstetric Unit of St. Sophia Hospital in Warsaw. The study group consisted of 88 women qualified for delivery to the Birth Centre, who commenced birth in the Birth Centre and finished it in the Obstetric Unit in 2017. The Birth Centre is located in the same building as the Obstetric Unit and is connected with it by a communication route. The total number of women who started birth at the Birth Centre was 888 , which determines the level of intrapartum transfers at $10 \%$. The analysis covered the demographic characteristics of women, the reasons for transfers, the way of finishing birth after the transfer and the birth status of the children.

The study was accepted for the attention of the Bioethical Commission of the Warsaw Medical University AKBE/232/2017.

\section{RESULTS}

Based on the analysis of medical documentation, it was established that the age of the surveyed women ranged from 23 to 38 . The most numerous group were women aged 30-34. Characteristics of the studied women are presented in table 1 . The vast majority of women giving birth was giving birth for the first time and has higher education (Tab. 1.). The highest percentage of transfers was recorded in the group of women who gave birth in the 40th week of pregnancy (Tab. 1.). On admission, in the obstetric examination, the majority of women had a cervix dilation smaller than $4 \mathrm{~cm}$ and intact fetal membranes (Tab. 1.).

Tab. 1. Characteristics of transferred women (88)

\begin{tabular}{|c|c|c|}
\hline Variables & $\mathbf{N}$ & $(\%)$ \\
\hline Age & 88 & $100 \%$ \\
\hline $20-24$ & 5 & $6 \%$ \\
\hline $25-29$ & 29 & $33 \%$ \\
\hline $30-34$ & 40 & $45 \%$ \\
\hline 35 and more & 14 & $16 \%$ \\
\hline Parity & 88 & $100 \%$ \\
\hline Primiparous & 73 & $83 \%$ \\
\hline Multiparous & 15 & $17 \%$ \\
\hline Number of born children & 88 & $100 \%$ \\
\hline 0 & 73 & $83 \%$ \\
\hline 1 & 12 & $14 \%$ \\
\hline 2 & 3 & $3 \%$ \\
\hline Education & 88 & $100 \%$ \\
\hline Secondary & 13 & $15 \%$ \\
\hline Higher & 75 & $85 \%$ \\
\hline Gestation (weeks) & 88 & $100 \%$ \\
\hline 37 & 2 & $2 \%$ \\
\hline 38 & 8 & $9 \%$ \\
\hline 39 & 28 & $32 \%$ \\
\hline 40 & 41 & $47 \%$ \\
\hline 41 & 9 & $10 \%$ \\
\hline Body mass index & 88 & $100 \%$ \\
\hline Underweight & 6 & $7 \%$ \\
\hline Correct weight & 36 & $41 \%$ \\
\hline Overweight & 5 & $6 \%$ \\
\hline Obesity & 0 & $0 \%$ \\
\hline no data & 41 & $46 \%$ \\
\hline Amniotic membranes on admission & 88 & $100 \%$ \\
\hline Intact & 52 & $59 \%$ \\
\hline Ruptured & 36 & $41 \%$ \\
\hline Cervical dilation on admission & 88 & $100 \%$ \\
\hline $1-3 \mathrm{~cm}$ & 80 & $91 \%$ \\
\hline $4-6 \mathrm{~cm}$ & 5 & $6 \%$ \\
\hline $7-10 \mathrm{~cm}$ & 3 & $3 \%$ \\
\hline
\end{tabular}


The analysis of the documentation showed that intrapartum transfers from the Birth Centre were related to either mother's obstetric condition, fetal condition or disturbance in the course of labour (Tab. 2.).

Tab. 2. Reasons for transfer from the Birth Centre to the Obstetric Unit $(\mathrm{N}=88)$

\begin{tabular}{|l|c|c|}
\hline \multicolumn{1}{|c|}{ Cause of transfer } & $\mathbf{n}$ & $\%$ \\
\hline Failure to progress of the $1^{\text {st }}$ stage of the labour & 23 & $26 \%$ \\
\hline Failure to progress of the $2^{\text {nd }}$ stage of the labour & 10 & $11 \%$ \\
\hline Meconium-stained amniotic fluid & 16 & $18 \%$ \\
\hline Epidural analgesia request & 15 & $17 \%$ \\
\hline Premature rupture of membranes & 8 & $9 \%$ \\
\hline Fetal heart rate abnormality & 11 & $13 \%$ \\
\hline Other & 5 & $6 \%$ \\
\hline
\end{tabular}

The failure to progress in the first stage of the labour was indicated most often (Tab. 2.). The next most common situations forcing the transfer were the meconium-stained amniotic fluid (18\%) and the woman's request for epidural analgesia (17\%). There were also transfers due to fetal heart rate abnormality and prolonged leakage of amniotic fluid, which was associated with the need to stimulate uterine contractions using oxytocin. There were isolated cases of intrapartum transfer associated with mother's infection, previously undiagnosed pelvic or bending position and leakage of blood-stained amniotic fluid difficult to evaluate.

The analysis of the documentation shows that despite the transfer, the childbirths ended in an operational or instrumental way only in about $1 / 4$ cases (Tab. 3.).

Tab. 2. Mode of delivery after the transfer $(\mathrm{N}=88)$

\begin{tabular}{|l|c|c|}
\hline \multicolumn{1}{|c|}{ Mode of delivery after the transfer } & $\mathbf{n}$ & $\%$ \\
\hline spontaneous delivery & 23 & $26 \%$ \\
\hline caesarean section & 10 & $11 \%$ \\
\hline vacuum extractor & 16 & $18 \%$ \\
\hline
\end{tabular}

The majority of children was born in a good condition, only 3 children were born with Apgar scores below 8 points in the $1^{\text {st }}$ and $3^{\text {rd }}$ minute of life (Tab. 4.).

Tab. 4. Apgar scores of newborns after the transfer $(\mathrm{N}=88)$

\begin{tabular}{|l|c|c|c|c|c|}
\hline & 6pkt & $\mathbf{7 p k t}$ & $\mathbf{8 p k t}$ & $\mathbf{9 p k t}$ & $\mathbf{1 0 p k t}$ \\
\hline 1 min. & 2 & 1 & 3 & 3 & 79 \\
\hline 3 min. & 0 & 1 & 5 & 1 & 81 \\
\hline 5 min. & 0 & 0 & 2 & 5 & 81 \\
\hline 10 min. & 0 & 0 & 2 & 3 & 83 \\
\hline
\end{tabular}

\section{DISCUSSION}

This study was aimed at analysing the causes of transfers of women starting their birth in the Birth Centre in 2017. Socio-demographic characteristics of those giving birth and the maternal and obstetric factors that may influence the need for transfer were described.
In the available literature, the main reasons for the transfers mention the failure to progress of the first and second stage of labour, meconium-stained amniotic fluid, abnormalities in the cardiotocograph and the request for epidural analgesia $[9,10,11,12]$. The same causes were indicated in the conducted studies. The failure to progress of the first stage of labour was the most common reason for transfer (26\% of cases). Another one is the meconium-stained amniotic fluid (18\%) and the request for an epidural anaesthesia (17\%).

The transfer rate in the world surveys varies from 5 to $20 \%$ [13]. These differences may result from the hospital's referentiality, medical staff, criteria taken into account in the qualification of the women to the Birth Centre. David reports that even with a good selection of risk factors, a transfer rate of $15-20 \%$ should be expected [13]. In own studies, the frequency of transfers amounted to $10 \%$, which shows that the qualification criteria used in the described Birth Centre allow for a good selection of women.

Giving birth for the first time was indicated in many studies as a factor strongly associated with the transfer of the woman. A general frequency of transfers of $11.8 \%$ was observed in the studies conducted in Denmark. Analysing the group of women giving birth for the first time and again separately, significant differences were noticed. Among the primiparous women, $37 \%$ were transferred, while among multiparous women only $7 \%$ [9]. In own research it was shown that the majority of transferred women were primipara. Out of 88 respondents, 73 gave birth for the first time. Considering the total number of primiparous women in the Birth Centre, it can be concluded that there is a $40 \%$ risk of transfer, while in the group of multiparous women it is $2.5 \%$.

In own studies, the highest percentage of transfers was observed in the group of women over 30 years of age. This is in line with the results of other authors. Da Silva reports that a higher mother's age is associated with a five times higher risk of transfer [12]. It has been proven that the increase in the mother's age correlates with the occurrence of complications of pregnancy and delivery [14]. It is also possible that midwives exhibit protection behaviours towards women who give birth at an older age, especially if they are giving birth for the first time.

The American studies from 2012 recorded a lower frequency of transfers among women of gestational age under 40 weeks [10]. This is confirmed in the conducted study, nearly $60 \%$ of transfers concerned women in the 40 th and 41 st week of pregnancy. This is due to the increased risk of complications after the date of delivery.

According to da Silva, women admitted to the Birth Centre with a dilation of up to $3 \mathrm{~cm}$ had nearly twice the risk of transfer in the intrapartum period. In this study, it was found that admission to the Birth Centre in the early stage of labour is associated with an increased anxiety about its course [12]. The stress experienced by women during admission to the institution may be reflected in the early stage of labour on the so-called effect of the admission room, inhibition of oxytocin secretion and result in the disturbed delivery. In own studies, as much as $90 \%$ of 
transferred women were admitted with cervical dilation of less than $4 \mathrm{~cm}$.

Research shows that women with higher education are more aware of childbirth, they have specific ideas about how they would like it to take place [15]. Therefore, in the Birth Centre a higher percentage of women with higher education is recorded, which also translates into a high percentage of women transferred with such education [16]. This was also confirmed by the results of our study.

One of the reasons for the transfers listed in the study was the premature rupture of membranes (PROM). An important role is played by the condition of the fetal membranes on admission to the Birth Centre. When it comes to $41 \%$ of those giving birth, they had a leakage of amniotic fluid. In the Brazilian study from 2012, the percentage of such women was lower, amounting to $23 \%$ [12].

The own study analysed the way of delivery after the transfer. Of the 88 women surveyed, $72 \%$ gave birth spontaneously. This shows that despite the necessity of a transfer, which is a stressful situation for both the woman and the therapeutic team, the medical staff made every effort to limit medical interventions and complete childbirth in a natural way. Caesarean section was performed in $18 \%$ of transferred women, and instrumental delivery with the use of vacuum extractor in $10 \%$ of the women. Other available studies have presented similar results. In 2016, David described the frequency of natural births after transfer at the level of $6 \%$. Caesarean section in these studies was performed in $22 \%$ of women, and instrumental delivery in $12 \%$ [13].
The condition of newborns born after the transfer was also analysed. On the Apgar Score, less than 8 points in the 1 st minute was achieved by $3.5 \%$ of newborns, in the 5 th minute it was only $1 \%$ of the born children. From these data one can conclude that the decision on the transfer in the described Birth Centre was made at the right moment before the complications affecting the children's birth status occurred. The proximity of the Obstetric Unit of the Hospital is crucial, with which the Birth Centre is directly connected and the availability of an obstetrician-gynaecologist, who can be asked for consultation. The obtained results are better than in the German studies published in 2006, where in the case of transporting the women giving birth to a more distant hospital, the percentage of newborns with the Apgar score below 8 points in the 1 st minute was $15 \%$, while in the $5^{\text {th }}$ minute it was $4 \%$ [17].

\section{CONCLUSIONS}

1. Proper qualification for delivery in the Birth Centre reduces the level of transfers to the Obstetric Unit.

2. The main reason for the transfer is failure to progress of labour.

3. Women giving birth for the first time, over 30 years old, with higher education, admitted for delivery after 40 weeks of pregnancy with ruptured membranes and the dilation under $4 \mathrm{~cm}$ are transferred the most frequently.

4. Close location of the Birth Centre and the Obstetric Unit impacts the risk reduction of perinatal complication.

\section{Analiza przyczyn transferów śródporodowych z Domu Narodzin do Oddziału Porodowego w roku 2017}

\section{WPROWADZENIE}

Do końca XIX wieku porody odbywały się głównie w domu [1]. Sytuacja zaczęła zmieniać się od drugiej połowy XX wieku. Poród stał się wydarzeniem medycznym, podlegającym procedurom szpitalnym i kontroli [2]. Doprowadziło to do znaczącego obniżenia śmiertelności i zachorowalności kobiet i noworodków, ale przyczyniło się także do tzw. „medykalizacji” położnictwa. Poród przyrównywano wręcz do zabiegów operacyjnych [3]. W latach siedemdziesiątych rozpoczęto likwidację Izb Porodowych prowadzonych przez położne. Związane to było z masowym powstawaniem w miastach placówek położniczo- ginekologicznych. Normą stało się rodzenie w szpitalu, a kompetencje położnej uległy stopniowemu ograniczeniu [1].

W ostatnich latach idea porodu naturalnego zaczęła się odradzać. Wiąże się to z zasadniczymi zmianami w zakresie opieki okołoporodowej. Rozporządzenie Ministra Zdrowia dotyczące standardów organizacyjnych opieki okołoporodowej, daje kobiecie prawo do świadomego wyboru miejsca porodu [4]. Według danych Światowej Organizacji Zdrowia naturalny poród dotyczy 70-80\% kobiet, nie musi odbywać się on w szpitalu [5]. W Polsce udział opieki alternatywnej wobec szpitala jest niewielki, jednak ciężarne coraz częściej decydują się na urodzenie dziecka z pomocą położnej, ale w warunkach pozaszpitalnych.

Ustawa z dnia 5 lipca 1996 roku o zawodach pielęgniarki i położnej podkreśla, że położna to osoba kompetentna do sprawowania samodzielnej opieki nad kobietą w ciąży fizjologicznej, przyjmowania porodu siłami natury oraz opieki nad noworodkiem i matką w okresie poporodowym [6]. Domy Narodzin prowadzone przez położne realizują wizję porodu w warunkach intymnych, zbliżonych do domowych, ale z zapewnieniem zaplecza szpitalnego, znajdującego się w bezpośredniej bliskości. Filozofią Domów Narodzin jest uznanie ciąży i narodzin jako naturalnego procesu w życiu kobiety [7]. Położne koncentrują się na holistycznej opiece nad rodzącą i jej rodziną, łącząc opiekę w sferze fizycznej, psychicznej 
i duchowej. Działania medyczne powinny być maksymalnie ograniczone, jednakże nie może odbywać się to kosztem bezpieczeństwa rodzącej i jej dziecka [8].

\section{CEL PRACY}

Celem pracy jest określenie przyczyn transferów z Domu Narodzin do Oddziału Porodowego oraz cech społeczno-demograficznych rodzących, które mogą predysponować do transferu.

\section{MATERIAŁ I METODYKA}

Badanie przeprowadzone zostało w oparciu o retrospektywną analizę dokumentacji medycznej rodzących transferowanych z Domu Narodzin do Oddziału Porodowego Szpitala św. Zofii w Warszawie. Grupę badaną stanowiło 88 kobiet zakwalifikowanych do porodu drogami natury do Domu Narodzin, które rozpoczęły poród w Domu Narodzin i ukończyły go w Oddziale Porodowym w roku 2017. Dom Narodzin znajduje się z tym samym budynku, co Oddział Porodowy i jest z nim połączony ciągiem komunikacyjnym. Całkowita liczba kobiet, które rozpoczęły poród w Domu Narodzin wynosiła 888, co określa poziom transferów śródporodowych na poziomie $10 \%$. Analizie poddano cechy demograficzne kobiet, przyczyny transferów, sposób ukończenia porodu po transferze oraz stan urodzeniowy dzieci.

Uzyskano zgodę Komisji Bioetycznej Warszawskiego Uniwersytetu Medycznego AKBE/232/2017 na prowadzenie niniejszych badań.

\section{WYNIKI}

Na podstawie analizy dokumentacji medycznej ustalono, że wiek badanych kobiet wahał się w przedziale od 23 do 38 lat. Najliczniejszą grupę stanowiły rodzące w wieku 30-34 lata. Charakterystyka badanych kobiet została przedstawiona $\mathrm{w}$ tabeli nr. I. Znacząca większość rodzących była pierworódkami oraz posiadała wykształcenie wyższe (tab. I). Największy odsetek transferów odnotowano w grupie kobiet, które rodziły w 40 tygodniu ciąży. Przy przyjęciu w badaniu położniczym u większości badanych stwierdzono rozwarcie szyjki macicy mniejsze niż $4 \mathrm{~cm}$ oraz zachowane błony płodowe (tab. 1).

Analiza dokumentacji wykazała, że transfery śródporodowe z Domu Narodzin związane były zarówno ze stanem położniczym matki, stanem płodu lub zaburzeniem przebiegu porodu (Tab. 2).

Najczęściej wskazywano na brak postępu porodu w I okresu (Tab. 2). Kolejne najczęstsze sytuacje zmuszające do transferu stanowiło odpływanie zielonego płynu owodniowego (18\%) oraz prośba kobiety o podanie znieczulenia zewnątrzoponowego (17\%). Odnotowano także transfery z powodu zaburzeń czynności serca płodu i przedłużającego się odpływania płynu owodniowego, co wiązało się z koniecznością stymulacji czynności skurczowej przy użyciu oksytocyny. Wystąpiły pojedyncze przypadki transferu śródporodowego związanego $\mathrm{z}$ infekcją matki, niezdiagnozowanego wcześniej położenia miednicowego płodu czy ułożenia odgięciowego oraz odpływania trudnego do oceny, podbarwionego krwią płynu owodniowego.

Tab. 1. Charakterystyka transferowanych kobiet $(\mathrm{N}=88)$

\begin{tabular}{|c|c|c|}
\hline Zmienne & N & (\%) \\
\hline Wiek & 88 & $100 \%$ \\
\hline $20-24$ & 5 & $6 \%$ \\
\hline $25-29$ & 29 & $33 \%$ \\
\hline $30-34$ & 40 & $45 \%$ \\
\hline 35 i więcej & 14 & $16 \%$ \\
\hline Rodność & 88 & $100 \%$ \\
\hline Pierworódka & 73 & $83 \%$ \\
\hline Wieloródka & 15 & $17 \%$ \\
\hline Liczba urodzonych dzieci & 88 & $100 \%$ \\
\hline 0 & 73 & $83 \%$ \\
\hline 1 & 12 & $14 \%$ \\
\hline 2 & 3 & $3 \%$ \\
\hline Wykształcenie & 88 & $100 \%$ \\
\hline Średnie & 13 & $15 \%$ \\
\hline Wyższe & 75 & $85 \%$ \\
\hline Ukończone tygodnie ciąży & 88 & $100 \%$ \\
\hline 37 & 2 & $2 \%$ \\
\hline 38 & 8 & $9 \%$ \\
\hline 39 & 28 & $32 \%$ \\
\hline 40 & 41 & $47 \%$ \\
\hline 41 & 9 & $10 \%$ \\
\hline BMI & 88 & $100 \%$ \\
\hline Niedowaga & 6 & $7 \%$ \\
\hline Prawidłowa waga & 36 & $41 \%$ \\
\hline Nadwaga & 5 & $6 \%$ \\
\hline Otyłość & 0 & $0 \%$ \\
\hline brak danych & 41 & $46 \%$ \\
\hline Stan błon płodowych przy przyjęciu & 88 & $100 \%$ \\
\hline Zachowane & 52 & $59 \%$ \\
\hline Pęknięte & 36 & $41 \%$ \\
\hline Rozwarcie przy przyjęciu & 88 & $100 \%$ \\
\hline $1-3 \mathrm{~cm}$ & 80 & $91 \%$ \\
\hline $4-6 \mathrm{~cm}$ & 5 & $6 \%$ \\
\hline $7-10 \mathrm{~cm}$ & 3 & $3 \%$ \\
\hline
\end{tabular}

Tab. 2. Przyczyny transferu z Domu Narodzin do Oddziału Porodowego $(\mathrm{N}=88)$

\begin{tabular}{|l|c|c|}
\hline \multicolumn{1}{|c|}{ Przyczyna transferu } & n & $\%$ \\
\hline Brak postępu I okresu porodu & 23 & $26 \%$ \\
\hline Brak postępu Il okresu porodu & 10 & $11 \%$ \\
\hline Odpływanie zielonego płynu owodniowego & 16 & $18 \%$ \\
\hline Prośba 0 znieczulenie zewnątrzoponowe & 15 & $17 \%$ \\
\hline Przedwczesne odpłynięcie płynu owodniowego & 8 & $9 \%$ \\
\hline Zaburzenia w czynności serca płodu & 11 & $13 \%$ \\
\hline Inne & 5 & $6 \%$ \\
\hline
\end{tabular}


Z analizy dokumentacji wynika, że mimo transferu porody zakończyły się w sposób operacyjny lub zabiegowy tylko w około 1/4 przypadków (Tab. 3).

Tab. 3. Sposób zakończenia porodu po transferze $(\mathrm{N}=88)$

\begin{tabular}{|l|c|c|}
\hline Sposób zakończenia porodu po transferze & $\mathbf{n}$ & $\%$ \\
\hline poród siłami natury & 63 & $72 \%$ \\
\hline cięcie cesarskie & 16 & $18 \%$ \\
\hline próżnociąg położniczy & 9 & $10 \%$ \\
\hline
\end{tabular}

Większość dzieci urodziła się w stanie dobrym, jedynie 3 dzieci urodziło się z punktacją poniżej 8 punktów Apgar stwierdzonych w 1 i 3 minucie życia (Tab. 4).

Tab. 4. Punktacja w skali Apgar noworodków urodzonych po transferze $(\mathrm{N}=88)$

\begin{tabular}{|l|c|c|c|c|c|}
\hline & 6pkt & 7pkt & 8pkt & 9pkt & 10pkt \\
\hline 1 minuta & 2 & 1 & 3 & 3 & 79 \\
\hline 3 minuta & 0 & 1 & 5 & 1 & 81 \\
\hline 5 minuta & 0 & 0 & 2 & 5 & 81 \\
\hline 10 minuta & 0 & 0 & 2 & 3 & 83 \\
\hline
\end{tabular}

\section{DYSKUSJA}

Badanie to miało na celu przeanalizowanie przyczyn transferów kobiet rozpoczynających w roku 2017 poród w Domu Narodzin. Opisano cechy społeczno- demograficzne tych rodzących oraz czynniki matczyne i położnicze mogące mieć wpływ na konieczność transferu.

W dostępnej literaturze jako główne przyczyny transferów wymieniane jest zahamowanie postępu I i II okresu porodu, odpływanie zielonego płynu owodniowego, zaburzenia w zapisie kardiotokograficznym oraz prośba rodzącej o znieczulenie zewnątrzoponowe $[9,10,11,12]$. W przeprowadzonych badaniach wskazano takie same przyczyny. Brak postępu I okresu porodu był najczęstszym powodem do transferu (26\% przypadków). Kolejne to odpływanie zielonego płynu owodniowego (18\%) oraz prośba rodzącej o znieczulenie zewnatrzoponowe (17\%).

Wskaźnik transferów w światowych badaniach waha się od 5 do 20\% [13]. Różnice te mogą wynikać ze stopnia referencyjności szpitala, personelu medycznego, kryteriów branych pod uwagę przy kwalifikacji rodzącej do Domu Narodzin. David podaje, że nawet przy dobrym doborze czynników ryzyka należy spodziewać się stopy transferów na poziomie $15-20 \%$ [13]. W badaniach własnych częstość transferów wyniosła $10 \%$, co pokazuje, że stosowane w opisywanym Domu Narodzin kryteria kwalifikacji pozwalają na dobrą selekcję kobiet rodzących.

Pierworództwo było wskazywane w wielu badaniach jako czynnik silnie związany $\mathrm{z}$ transferem rodzącej. W badaniach przeprowadzonych w Danii zaobserwowano ogólną częstość transferów wynoszącą 11,8\%. Analizując oddzielnie grupę pierwiastek i wieloródek zauważono znaczące różnice. Wśród pierwiastek transferowane było 37\% rodzących, zaś wieloródek jedynie 7\% [9]. W badaniach własnych wykazano, że większość kobiet transferowa- nych była pierworódkami. Z 88 badanych aż 73 rodziły po raz pierwszy. Biorąc pod uwagę ogólną liczbę pierworódek rodzących w Domu Narodzin można stwierdzić, że istnieje $40 \%$ ryzyka transferu, zaś w grupie wieloródek jest to 2,5\%.

$\mathrm{W}$ badaniach własnych największy procent transferów zaobserwowano $\mathrm{w}$ grupie kobiet po 30 roku życia. Jest to zgodne z wynikami innych autorów. Da Silva podaje, że wyższy wiek matki wiąże się z pięciokrotnie wyższym ryzykiem transferu [12]. Udowodniono, że wzrost wieku matki koreluje $\mathrm{z}$ występowaniem powikłań ciąży i porodu [14]. Możliwe jest też, że położne wykazują zachowania asekuracyjne wobec kobiet, które rodzą w późniejszym wieku, szczególnie jeśli są pierworódkami.

W amerykańskich badaniach z 2012 roku odnotowano mniejszą częstość transferów wśród kobiet $\mathrm{w}$ wieku ciążowym poniżej 40 tygodnia [10]. Potwierdza się to w przeprowadzonym badaniu, blisko $60 \%$ transferów dotyczyło kobiet w 40 i 41 tygodniu ciąży. Wynika to ze wzrostu ryzyka powikłań po terminie porodu.

Według da Silvy kobiety przyjęte do Domu Narodzin $\mathrm{z}$ rozwarciem do $3 \mathrm{~cm}$ miały blisko dwukrotnie wyższe ryzyko transferu w okresie śródporodowym. W badaniu tym stwierdzono, że przyjęcie do Domu Narodzin we wczesnej fazie porodu wiąże się ze wzrostem niepokoju o jego przebieg [12]. Stres, którego doświadczają kobiety podczas przyjęcia do placówki, może przekładać się we wczesnej fazie porodu na tzw. efekt izby przyjęć, zahamowanie wydzielania oksytocyny i skutkować zaburzeniem przebiegu porodu. W badaniach własnych, aż $90 \%$ transferowanych rodzących było przyjęte $\mathrm{z}$ rozwarciem szyjki macicy mniejszym niż $4 \mathrm{~cm}$.

Badania wykazują, że kobiety z wyższym wykształceniem są bardziej świadome, co do porodu, posiadają określone wyobrażenia na temat tego, jak chciałyby żeby on przebiegał [15]. W związku z tym w Domu Narodzin odnotowuje się wyższy procent rodzących $\mathrm{z}$ wyższym wykształceniem, co przekłada się również na wysoki odsetek transferowanych kobiet $\mathrm{z}$ takim wykształceniem [16]. Potwierdziły to również wyniki naszego badania.

Jedną $\mathrm{z}$ wymienianych $\mathrm{w}$ badaniu własnym przyczyn transferów był przedwczesne odpłynięcie płynu owodniowego (PROM). Istotną rolę odgrywa więc stan błon płodowych przy przyjęciu kobiety do porodu. $41 \%$ rodzących miało stwierdzone odpływanie płynu owodniowego. W badaniu brazylijskim z 2012 roku odsetek takich kobiet był niższy, wynosił $23 \%$ [12].

W badaniu własnym przeanalizowano sposób ukończenia porodu po transferze. Wśród badanych 88 kobiet $72 \%$ z nich urodziło w sposób naturalny. Pokazuje to, że mimo konieczności transferu, który jest stresującą sytuacją zarówno dla kobiety, jak i zespołu terapeutycznego, personel medyczny dokładał wszelkich starań by ograniczyć interwencje medyczne i ukończyć poród w sposób naturalny. Cięcie cesarskie wykonano u 18\% transferowanych kobiet, zaś poród zabiegowy przy pomocy próżnociągu położniczego u $10 \%$ rodzących. W innych dostępnych badaniach uzyskano podobne wyniki. W 2016 roku David opisał częstość porodów naturalnych po transferze na poziomie $66 \%$. Cięcia cesarskie w tych badaniach wykonano u $22 \%$ kobiet, zaś poród zabiegowy - $12 \%$ [13]. 
Analizie poddano także stan noworodków urodzonych po transferze. W skali Apgar punktację niższą niż 8 punktów w 1 minucie uzyskało 3,5 \% noworodków, w minucie 5 było to już tylko $1 \%$ urodzonych dzieci. $Z$ danych tych można wyciągnąć wniosek, że decyzje o transferze w opisywanym Domu Narodzin były podejmowane w odpowiednim momencie, zanim zdążyły wystąpić powikłania wpływające na stan urodzeniowy dzieci. Kluczowa jest bliskość Oddziału Położniczego Szpitala, z którym Dom Narodzin jest bezpośrednio połączony oraz dostępność lekarza położnika-ginekologa, który może zostać poproszony na konsultację do Domu Narodzin. Otrzymane wyniki są lepsze niż w niemieckich badaniach opublikowanych w 2006 roku, gdzie w przypadku przewożenia rodzących do bardziej oddalonego szpitala, odsetek noworodków z punktacją Apgar poniżej 8 punktów w 1 minucie wynosił 15\%, zaś w 5 minucie było to 4\% [17].

\section{WNIOSKI}

1. Prawidłowa kwalifikacja kobiet do porodu w Domu Narodzin zmniejsza częstość transferów do szpitala.

2. Główną przyczyną transferów rodzących jest zahamowanie postępu porodu.

3. Najczęściej transferowane są pierworódki po 30 roku życia, z wykształceniem wyższym, przyjęte do porodu po 40 tygodniu ciąży z odpływającym płynem owodniowym i rozwarciem poniżej $4 \mathrm{~cm}$.

4. Bliskie usytuowanie Domu Narodzin i Oddziału Porodowego wpływa na ograniczenie ryzyka powikłań okołoporodowych dla matki i dziecka.

\section{PIŚMIENNICTWO/REFERENCES}

1. Wrześniewska M, Bąk B. Historia zawodu położnej i kształtowanie się opieki okołoporodowej na świecie i w Polsce. Studia Medyczne. 2012; 27(3):89-99.

2. Gierszewska M, Kwiatkowska W, Kaźmierczak M. Poród domowy - anachronizm czy wybór i potrzeba świadomych kobiet? Perinatologia, Neonatologia i Ginekologia. 2013; 6(4):220-224.

3. Dziedzic M, Matuszyk D. Prażmowska B. Poród domowy w opinii położnych. Problemy Pielęgniarstwa. 2011; 19(2):153-161.

4. Rozporządzenie Ministra Zdrowia z dnia 16 sierpnia 2018 r. w sprawie standardu organizacyjnego opieki okołoporodowej. Dz.U. 2018; poz. 1756.

5. Pankrac Z, Filipska-Kozak E, Hofman A. Realizacja praw pacjenta podczas porodu w szpitalu. Zdrowie i Dobrostan. 2015;2(1):297-308.

6. Ustawa z dnia 5 lipca 1996 r. o zawodach pielęgniarki i położnej, (Dz.U. 1996 nr 91 poz. 410).

7. Doroszewska A. Społeczne role położnych. Analiza zawodu położnej z perspektywy socjologii zawodów medycznych. Warszawa: Naczelna Izba Pielęgniarek ¡ Położnych; 2013, s.74-78.

8. Larsen N. Birthing Center versus Hospitalized Birth. CrissCross. 2016; 4(1):1-17.

9. Overgaard C, Moller AM, Fenger-Gron M, Knudsen LB. Freestanding midwifery unit versus obstetric unit: a matched cohort study of outcomes in low-risk women. BMJ Open. 2011;1e:000262.doi:10.1136/bmjopen-2011-000262

10. Rowe R, Fitzpatrick R, Hollowell J, Kurinczuk J. Transfer of women planning birth in midwifery units: data from the Birthplace prospective cohort study. BJOG. 2012; 119:1081-1090.

11. Bonadio IC, Schneck CA, Pires LG, Osava RH. Transferring mothers from a freestanding birth center to a reference hospital. Rev Esc Enferm USP. 2011; 45(6):13011307

12. Barbosa da Silva FM, Schneck CA, Bick D, Osava RH. Factors associated with intrapartum transfers from a freestanding birth centre in Sao Paulo, Brazil: A case control study. Midwifery. 2012; 28:646-652

13. David M, Berg G, Werth I, Pachaly J. Intrapartum transfer from a birth centre to a hospital- reasons, procedures and consequences. Acta Obstetricia et Gynecologica. 2006; 85:422-428

14. Lisowska S. Ryzyko związane z ciążą po 35 roku życia. Małopolskie Pielęgniarki Położne. 2013; 6:12-15.

15. Puszczałowska-Lizis E, Mokrzycka K, Jandziś S. Wpływ edukacji przedporodowej na przebieg ciąży, porodu i wczesne macierzyństwo. Medycyna Ogólna iNauki 0 Zdrowiu. 2016; 22(4):264-269.

16. Houghton G, Bedwell C, Forsey M, Lavender T. Factors influencing choice in birth place- An exploration of the views of women, their partners and professionals. Evidence Based Midwifery. 2008; 6(2):59-64.

17. Lundeen T. Intrapartum and postpartum transfers to a tertiary care hospital from out-of-hospital birth settings: a retrospective case series. J Midwifery Women's Health. 2016; 61:242-248.

Praca zgłoszona do czasopisma/Manuscript received: 19.02.2019

Praca zaakceptowana do druku/Manuscript accepted 27.02.2019

Tłumaczenie/Translation: Ewa Gurdak 